\title{
Spatial Analysis of Urban Water Use Management in the Northern Border Region of Mexico
}

\author{
Gregorio Castro-Rosales ${ }^{1} \&$ Ramiro Esqueda-Walle ${ }^{2}$ \\ ${ }^{1}$ Department of Agricultural Economics, Autonomous Agrarian University Antonio Narro, Saltillo, Mexico \\ ${ }^{2}$ Rio Bravo Multidisciplinary Academic Unit, Autonomous University of Tamaulipas, Rio Bravo, Mexico \\ Correspondence: Ramiro Esqueda-Walle, Autonomous University of Tamaulipas, Rio Bravo, Tam., Mexico, C.P. \\ 88925. E-mail: resquedaw@uat.edu.mx
}

Received: January 11, 2020

doi:10.5539/ijbm.v15n11p126

\author{
Accepted: September 30, 2020 \\ Online Published: October 21, 2020 \\ URL: https://doi.org/10.5539/ijbm.v15n11p126
}

\begin{abstract}
This paper estimates water price elasticity and examines spatial patterns of urban water management variables in 70 localities of more than 2500 inhabitants of the six northern border Mexican states. By using ordinary least squares, spatial econometrics, Lagrange Multipliers, and exploratory spatial data analysis techniques, four variables were analyzed: water price $(\mathrm{P})$, a Non-revenue water index (NRWI), total urban water connections, and water billed volume (BV). In accordance with the literature, we found that water demand is price sensitive but inelastic. Then price as an instrument for controlling water consumption does not offer an efficient alternative for reducing it, as water price increases would have to rise very high to reflect changes in consumption habits. Instead, it could be just a revenue-raising tool. Our findings also confirm a significant spatial autocorrelation in $\mathrm{P}$ and the NRWI. More interestingly, we found robust spatial effects on BV. This result implies that the performance of urban water utilities is determined by its counterparts' performance in the region. Given the results and characteristics of water resources in the region, we argue that management policies must consider a regional approach to be effective.
\end{abstract}

Keywords: Non-revenue water index, Northern border region of Mexico, spatial econometrics, spatial error model, spatial analysis, urban water, water management, water price

\section{Introduction}

According to official data and estimates (INEGI, 2015; CONAPO, 2018), the urban population share in Mexico in 2018 was $81 \%$ (Note 1), which is much higher than the average world urbanization rate of 56 percent for the same year (Note 2). This trend resulted from a constant transformation in the population structure in a relatively short period, as the share increased from 42.6 percent in 1950 to 66.3 percent in 1980 and, since then, to 81 percent in the most recent estimate. However, this distribution pattern at the regional level is heterogeneous, even if analyzed at the mesoregional level. Among these, the six Northern Border States (NBS from here on; Baja California, Sonora, Chihuahua, Coahuila, Nuevo León, and Tamaulipas; Figure 1) stand out where the urban population is 91 percent on average; in fact, 83 percent live in towns with more than 20000 inhabitants.

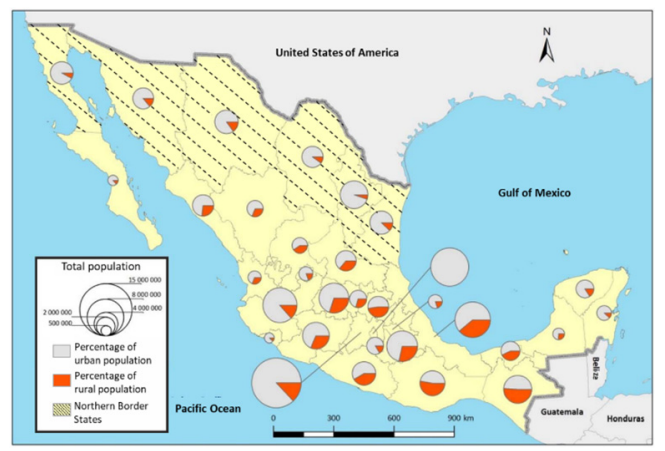

Figure 1. Map of Mexico: study region and urbanization percentages by state (2018)

Source: INEGI, CONAPO and authors' elaboration. 
The structure of geographical distribution of population and its increasing trend to move to larger urban areas impose a significant challenge in guaranteeing access to water in sufficient quantity and quality, both for current and future generations. For this reason, the article focuses on the NBS region as a case study, specifically on 70 localities with more than 2500 inhabitants (Note 3) (see Appendix).

According to the Public Registry of Water Rights at the end of July 2018, 56 percent of urban water in the six states on the northern border is drawn from underground sources. However, there is a marked disparity in the composition of them. While Baja California, Nuevo León, and Tamaulipas supply 61, 70, and 88 percent from surface sources, Coahuila, Chihuahua, and Sonora extract 89, 92, and 64 percent (respectively) from underground sources. In this context, given the predominance of groundwater sources at the regional level, guaranteeing supply is undoubtedly more difficult due to the water table's long-term recovery implications (Note 4).

Beyond the conditions of population concentration, supply sources, and the natural availability of water in the region, it is critical to analyze the performance of the urban water utilities (UWU) (Note 5), as they oversee urban water management in Mexico. However, it is not just a challenge for Mexico as with two-thirds of the world's megacities located in regions that are vulnerable to the impacts of climate change; urban water utilities are facing an increasing need to improve the management of water resources and associated infrastructure (Danilenko, Dickson and Jacobsen (2010). As Bunge (2010) and Ruiz (2010) point out, the problems of access and water availability are not necessarily due to population growth, but rather to its use and management.

In the NBS, there are a total of 78 (Note 6) UWU; one is a private licensee, two mixed (public-private partnerships), and the rest are public. The main legal instruments that govern water operating agencies at the national level are the Federal Political Constitution and the National Water Law. The management of these organizations is ruled by the latter and establishes that the use or exploitation of national waters will be carried out through a concession or license granted by the Federal Executive. It is clear from the legislation that access to water is not only a service but also a human right that should be guaranteed to all persons. However, an operating water agency may belong to a private organization, be administered by it, and be supervised by a federal entity. Notably, the legal framework does not establish administrative, nor profitability and financial performance criteria.

Many researchers agree that the biggest problem lies in the performance of UWU, as they have no clear objectives in their functions and no incentives for efficiency. However, they also emphasize that each town has different water consumption patterns that impact their operations and administrative efficiency (Barkin \& Klooster, 2006; Contreras, 2006; Satterthwaite, 2007; Salazar \& Pineda, 2010). As water supply is almost entirely provided by public entities, the rule of law and institutional quality are elements that influence operational and financial results; however, the latter is not included directly in our analytical model.

Given the magnitude of the challenges and problems, various proposals have been developed to improve the use of urban water, which, by the way, does not represent the largest volume of consumption, concerning uses such as agriculture and industry, is one of the most sensitive, since the loss of social well-being is immediate in the face of any factor that hinders its provision. In sum, it is a very relevant topic since urban water utilities are crucial to the economic, environmental, and social health of urban areas, as Ries et al. (2016) state.

This paper's purpose is twofold: first, to estimate water price elasticity and analyze factors that influence urban water consumption in the northern border towns, and second, to identify regional patterns by spatial dependence and spatial association. Hence, this research contributes to the studies done so far (in Mexico), especially at the regional level, and offers empirical evidence with potential usefulness in decision making in this area.

After the introduction, the article is organized as follows: Section 2 provides an overview of previous international and national studies on urban water management, while Section 3 presents the analytical framework and methodology. Section 4 presents and discusses the results. Finally, Section 5 provides the conclusion and implications of the study.

\section{Literature Review}

Although water studies are copious, from an economic perspective, their approach is relatively recent, particularly in terms of demand analysis. According to Dalhuisen et al. (2001), the first work dates from 1951, mostly conducted in the United States and more recently in Europe. Based on this, Dalhuisen et al. (2003) researched the disparities in the values of price and income elasticities estimated in sixty-four different works between 1963 and 2001 on domestic water demand, in which average price elasticity of -0.41 and average income elasticity of 0.43 were found. In a similar vein, previous work is the one of Espey et al. (1997), who analyzed the estimates for the price elasticity of residential water demand, published in 24 articles during 1967 and 1993, finding an average elasticity of -0.51 . Another paper that also compiles and analyzes international literature is from Arbués et al. 
(2003). They focus on the general characteristics, the technical specifications applied, and the difficulties encountered in estimating residential water demand in the studies carried out in the United States and Europe.

On the other hand, focusing on developing countries, Nauges and Whittington (2010) thoroughly review the previous literature on residential water demand. They find that there are essential differences in contrast to developed countries in the number of studies conducted and the difficulties in carrying them out due to the shortage of information and data availability. Despite this, the findings are very similar, as price elasticities of demand ranged from -0.3 to -0.6 , while income elasticities of demand were between 0.1 and 0.3 ; however, they highlight that these figures can have different impacts from a developed to a developing country.

House-Peters and Chang (2011) carried out a study of the art of water demand by considering the literature published from 1978 to 2010. They identified a total of three hundred and four, with a growing trend from 2005 when the highest number of publications on the subject were recorded. The authors' analysis focuses on methodological frameworks developed to make empirical estimates and on the independent variables included. Most studies consider price, user income, climate variables, and socioeconomic characteristics of users and households. The latter undoubtedly reveals how the interest in understanding the determinants of urban water demand has become critical.

In a more recent literature review, Reynaud and Romano (2018) found a consensus that residential water demand is inelastic regarding its price, but not perfectly. They add that given the low water price elasticity, pricing schemes may not always be useful tools for modifying household water behaviors, which is ambiguous as public authorities still view increasing the water price as the most direct economic tool for inducing water conservation behaviors. However, they suggest that additional evidence on public policy in shaping residential water use is then required.

In the case of Mexico, little work has been done on water demand. Most of them are local studies and with more emphasis on domestic use, for which in terms of price and income elasticities of demand, the findings generally match the average ranges calculated in the international literature. Among the first ones is Jaramillo-Mosqueira (2003), who analyzed the demand for water for domestic use in 750 households in three Estado de México municipalities. He stated that the price elasticity of demand increases as the consumption block increases, ranging from -0.22 to -0.58 , while some other variables associated with income levels were positively related to consumption.

In turn, Fullerton and Nava (2003) and Fullerton et al. (2007) estimated a function of monthly urban water demand for Chihuahua, Ciudad Juárez, and Tijuana, respectively. In both empirical studies, water consumption per user was considered as a dependent variable, whose volume is added and independent of the type of use. In general, results they found to be relevant were the significance of explanatory variables and rapid response to climatic variables and economic performance.

Another work that also analyzes the monthly water demand, but only for domestic use, is that by Garcia and Mora (2008) for the cities of Torreón (Coahuila) and Gómez Palacio (Durango). Based on the function of estimated water demand per household, they encountered that price elasticity of demand was -0.20 for the former and -0.18 for the latter, while income elasticity was 0.94 and 0.98 , respectively.

In the study by Guzmán et al. (2009), the demand for groundwater in Guanajuato is analyzed for agricultural, livestock, industrial, and urban uses, estimating the following price elasticities of demand. For urban use -0.015 ; for livestock -0.0038; agriculture -0.052; and for industrial use -0.126 .

On the other hand, Salazar and Pineda (2010a) analyzed the case of residential water demand in the city of Hermosillo (Sonora). For this purpose, they estimated a national demand function that allowed them to perform the analysis for this city, using the volume billed per capita as the dependent variable. The key results were that the variables household size and temperature were not significant and that price elasticity of demand, at a national level, was -0.27 , while that of income was 0.21 .

In another study, these authors (Salazar \& Pineda, 2010b) analyzed the demand for water for domestic use in Mexico for 1996-2001 and a sample of one hundred thirty-four localities of more than 30000 inhabitants. From the data, they formed an unbalanced panel and computed a demand function like the previously cited work. In their estimates, the price elasticity of demand was -0.33 , and that of income was 0.2 .

In the work of Sisto (2010), the demand for urban public water in the metropolitan area of La Laguna is analyzed, implementing a demand function in which the dependent variable is the volume demanded per connection and the explanatory variables: the cost of water, the share of domestic connections and as a dichotomous variable the position of connections. In his results, he finds a price elasticity of demand that varies around -0.47 and -0.53 . Finally, in a report from the Water Advisory Council (2010), an econometric model is developed to analyze per 
capita water demand in a sample of sixty cities in the country. The result is the price elasticity of demand -0.29 and the income of 0.32 .

In one of the most recent studies, Avilés-Polanco, Almendarez-Hernández, Hernández-Trejo, and Beltrán-Morales (2015), analyze the city of La Paz, Baja California Sur, for being an arid coastal zone with water supply restrictions to estimate the short- and the long-term price elasticity of residential water demand and to weigh the impact that a block price structure has on efficient use. The short- and long-term elasticities of demand were higher than the average in the national empirical literature, which indicates that the magnitude of the adjustment of water consumption in the face of sustained price increases is more significant than in other regions of Mexico. At the same time, increases in temperature and income also influence the growth in demand. They state that water resources management plans in regions with supply restrictions should consider applying price-based instruments for managing urban water demand since households adjust their water consumption levels in the face of sustained increases in block price structure to achieve efficient use of the resource. The results of the short-term price elasticity estimates in the cross-section and time series model were -0.56 and -0.51 , respectively, while the longterm price elasticity was -0.90 .

From the literature review, it is possible to state that our paper represents an important contribution to the analysis of urban water demand in Mexico. On the one hand, it analyzes the total urban public use of water and not only per household as done in most studies. On the other hand, a function of total water demand is estimated, in contrast to the per capita or per connection functions of previous studies, which analyzes current demand behavior's environmental impact. Undoubtedly, one of the central insights of this article is the analyses of water price determinants, even considering the role of possible effects associated with spatial dependence. Besides, our approach contributes to evaluate the potential of this instrument in controlling demand and its role to improve the financial performance of UWU.

\section{Methodology}

Data were obtained from CONAGUA (2014), where a sample of 70 UWU operating in towns (Note 7) of more than 2500 inhabitants in the six states of the northern border of Mexico was collected. The database provides information for 2013 (Note 8) on the population supplied by each UWU, including the total urban water connections, revenues collected, extracted water volume, daily average water supply, and billed water volume. From the data we proxied as efficiency variables, the Non-revenue Water Index (NRWI) and water price estimated as follows:

$$
N R W I=\frac{E V-B V}{E V}
$$

Where $N R W I$ is expressed in percentage, $E V=$ water extracted volume $\left(\mathrm{m}^{3}\right), B V=$ water billed volume $\left(\mathrm{m}^{3}\right)$.

The price was estimated as follows:

$$
P=\frac{R}{B V}
$$

Where $P=$ average price per cubic meter (pesos), $R=$ revenues collected from urban water utilities (pesos) (Note 9).

By using the same variables, the estimation of a water demand model such as proposed by Castro and Sisto (2015) was carried out, as follows:

$$
\ln B V=\beta_{0}+\beta_{1} \ln P+\beta_{2} \ln N R W I+\beta_{3} \ln C O N N+u
$$

Where the variable CONN refers to the total urban water connections by each town. The functional form of the model is logarithmic because the estimators are intended to be in terms of elasticities. The model estimation method is Ordinary Least Squares (OLS).

Exploratory Spatial Data Analysis (ESDA) is then performed at the univariate level for water price, daily average water supply, and NRWI. ESDA is a methodology that considers the role of spatial effects. In this regard, Anselin (1994 and 1996) proposes that for the analysis of regions, mainly small ones, the existence of two types of spatial effects should be considered: spatial autocorrelation and heterogeneity. It consists of a set of techniques to describe and visualize spatial distributions, identify spatial outliers, discover spatial association patterns (clusters, hot spots, cold spots) and suggest spatial structures (regimes) (non-stationary) or other forms of spatial heterogeneity (Anselin, 1996; Messner et al., 1999). This methodology is based on tools that are descriptive (statistical) rather 
than confirmatory (econometric) in nature, although the detection of spatial structures in the geographical variables makes it possible to formulate prior hypotheses for econometric modeling and, where appropriate, the spatial prediction of new data (Chasco, 2003; Esqueda, 2018). Spatial effects are the fundamental reason for understanding the logic of interaction between observations and, among them, the following stand out:

(i) Spatial dependence, in general terms, refers to the existence of a functional relationship between what happens at one point in space and what happens at rest. Two conditions could lead to this situation. The first may be the result of measurement errors in observations of adjacent space units. The second is more relevant to regional science and human geography and results from a diversity of spatial interaction phenomena.

(ii) Spatial heterogeneity; Anselin (1988) points out that in the literature of regional science and economic geography, there is extensive evidence of non-uniformity of space effects. Thus, spatial heterogeneity implies that economic performance is not stable in space and can generate spatial patterns of development in the form of spatial regimes, for example, a cluster of rich regions (the center) in contrast to a conglomerate of poor regions (the periphery) (Le Gallo \& Ertur, 2003).

(iii) Spatial autocorrelation; while often equated with spatial dependence effect, Anselin (1988) argues that this is a different approach, as the data are used to infer an appropriate form of dependence. Le Gallo and Ertur (2003) define spatial autocorrelation as the coincidence of value similarity with locational similarity.

Different statistics measure the global spatial association, the gamma statistic, the union count statistic, Geary's C, and Moran's I. Since the latter is used in this paper, its characteristics are presented below. Moran's I provide us a global vision of spatial interrelationship processes of variables, but it does not show autocorrelation's local structure (Dall'erba, 2003). The estimation of the referred statistic is obtained by the following expression:

$$
I_{t}=\frac{\mathrm{N} \sum_{i} \sum_{j} w_{i j}(k) x_{i t} x_{j t}}{\mathrm{~N} \sum_{i} \sum_{j} x_{i t} x_{j t}}
$$

Where $W_{i j}$ is the degree of connection (standardized by line) between spatial units $i$ and $j$ and $X_{i t}$ which is the variable of interest in town $i$ in year $t$ (measured as a deviation from the mean value for that year). Statistical values greater or less than the expected value $E(I)=(-1) /(N-1)$ indicate positive or negative spatial autocorrelation (Anselin, 1996). When Moran's I values are close to 1, it can be said that the variable presents a strong positive dependence, this means similar values tend to be together in space. Similarly, values close to (-)1 show a strong negative dependence (dissimilar values close to each other), and values around $(-1) /(n-1)$ denote a random distribution. By considering extreme values, Figure 2 represents theoretical patterns for different types of autocorrelation.

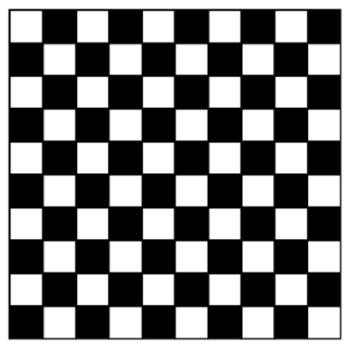

Negative spatial

autocorrelation $I=-1$

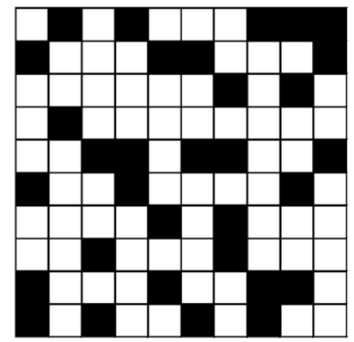

Random spatial

autocorrelation $I=0$

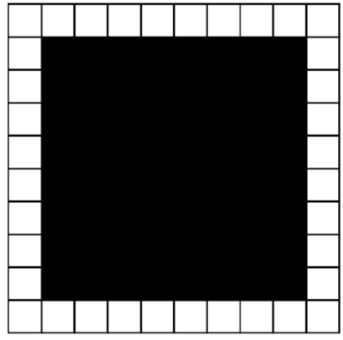

Positive spatial

autocorrelation $I=1$

Figure 2. Patterns and extreme values of spatial autocorrelation using Moran's I (Esqueda, 2018).

Afterward, we applied the method proposed by Anselin (2004) to perform a confirmatory analysis of the spatial association through a regression model. This procedure consists of estimating the model by OLS, and then a spatial autocorrelation test is performed on the residuals of this estimate. Through Moran's I, the existence of spatial association in the residuals is verified. In an affirmative case, the simple and robust Lagrange multipliers test is performed to identify the type of autocorrelation (see Anselin, 1995). The test 
result provides clues about the spatially specified model that is suitable to improve the goodness of fit of the regression. One of the models for capturing spatial effects is the so-called spatial error model (Arbia, 2014):

$$
y=X \beta+\varepsilon
$$

With:

$$
\varepsilon=\lambda W \varepsilon+u
$$

Where, $y=$ a vector of observations of the dependent variable, $W=$ is the spatial weights matrix, $X=$ is a matrix of observations of the exogenous variables, $\varepsilon=$ is a vector of the spatially autocorrelated error terms, $u=$ is a vector of independent and identically distributed error terms, $\beta$ and $\lambda$ are parameters.

Another model suggested in the procedure is that of spatial lag, whose general form is as follows:

$$
y=\rho W y+X \beta+u
$$

Where $W y$ is the spatial lag of the variable $y$ with its respective parameter $\rho$, while the rest of the variables and parameters nomenclature is the same used in the spatial error model. An essential tool for spatial analysis is the contiguity matrix that weights the level of interaction between spatial units, which in this case are the polygons of the localities of more than 2500 inhabitants of the NBS. Thus, the spatial weighting matrix $(W)$ represents the structure of the spatial relationship between different points. Therefore, it enables a variable at one point in space to be related to observations in other spatial units of the system and is used as a variable when modeling spatial effects within the data. The computed W-matrix records the interactions with the criteria described as follows:

$$
W=\left[\begin{array}{cccc}
0 & w_{12} & \ldots & w_{1 N} \\
w_{21} & 0 & \ldots & w_{2 N} \\
\vdots & \vdots & \vdots & \vdots \\
w_{N 1} & w_{N 2} & \ldots & 0
\end{array}\right]
$$

According to Moreno and Vayá (2000) and Acevedo and Velásquez (2008), several criteria are considered for its construction, some based on physical contiguity and others on distance. In this paper, an inverse distance approach is considered as the one used by Castro (2014) based on Anselin (1980):

$$
w_{i j}=d_{i j}^{-2}
$$

Where wij is the weighting representing the influence of region $j$ on region $i$; and $d i j$ is the Euclidean distance between regions $i, j$. In this case, all localities are neighbors, but their interaction decreases as the distance increases. We consider this criterion appropriate given that the sample of spatial units is small, so adopting the one developed by Castro (2014) may result in too many isolated polygons, which may not fully reflect the possible interaction between study units.

This methodology is intended to estimate the price elasticity of demand and identify the spatial patterns of water management variables in the northern border states' urban localities.

\section{Results and Discussion}

The descriptive statistics of variables analyzed in this paper are shown in Table 1. The average price charged for the sample of UWU is 6 pesos, but there is a high disparity between the minimum value charged and the maximum. While there are some that charge less than one peso per cubic meter, there are others that charge more than 18 pesos (see Table 1). This is interesting because the same disparity was found in Castro and Sisto (2015), who analyzed this variable at the national level.

Table 1. Descriptive statistics on water management variables for UWU (2013)

\begin{tabular}{llll}
\hline Variables & Mean & Minimum & Maximum \\
\hline$B V$ & 13600000 & 116000 & 261000000. \\
$N R W I$ & 46.30 & 14.30 & 68.50 \\
$C O N N$ & 63600 & 611 & 1160000 \\
$P$ & 6.11 & 0.90 & 18.60 \\
\hline
\end{tabular}

Source: Authors' elaboration based on data from CONAGUA (2014). 
The billed volume and total connections also reveal a significant disparity; though, this is related to the number of users at each location. Finally, one of the most interesting variables is NRWI, an efficiency measure of UWU performance. At least one holds an acceptable level of efficiency because it only registers 14 percent of unbilled water. In contrast, there is another that exhibits a very high percentage of unbilled volume, nearly 69 percent, leading to a very high NRWI on average, which is not convenient in terms of efficiency. This pattern suggests the need to undertake more in-depth analysis in order to identify factors influencing this behavior.

The results of the OLS regression for the model proposed in equation 3 are shown in Table 2. Regarding the price, it was found that billed volume is inelastic to it, which is consistent with the findings in both the national and international literature. Nevertheless, except for Castro and Sisto (2015), total connections and the NRWI had not been considered in previous research. In doing so, our study also represents a contribution to the contrast of results. It is clear, the more inefficient a UWU is, the less volume it has. While if the number of water users increases, the volume billed tends, on average, to increase.

Table 2. OLS regression; determinants of water billed volume (ln BV)

\begin{tabular}{|c|c|c|c|c|c|c|c|c|}
\hline & Constant & $\ln N R W I$ & $\ln P$ & $\ln C O N N$ & Observations & Adjusted R square & $\ln \mathrm{L}$ & Akaike criterion \\
\hline Coefficient & $5.92 * * *$ & $-0.16^{*}$ & $-0.27 * * *$ & $1.04 * * *$ & & & & \\
\hline t Stat & 14.02 & -1.88 & -6.82 & 59.04 & 70 & 0.986 & 10.651 & -13.302 \\
\hline P-Value & 0.0001 & 0.0647 & 0.0001 & 0.0001 & & & & \\
\hline
\end{tabular}

While the above model provides evidence on the regional determinants of urban water pricing, we cannot yet confirm any spatial effect. For this purpose, ESDA is implemented using Moran's I described in the methodology (equation 4). The results are illustrated by univariate Moran scatter diagrams. Except for CONN, the rest of the variables exhibited significant high levels of spatial autocorrelation. This result implies that there is agglomeration between similar values of the variable. The ones that charge more for water are agglomerated among themselves, like those that charge less (Figure 3). Also, in the case of the NRWI (Figure $4)$, there is a spatial association between similar values of respective variables.

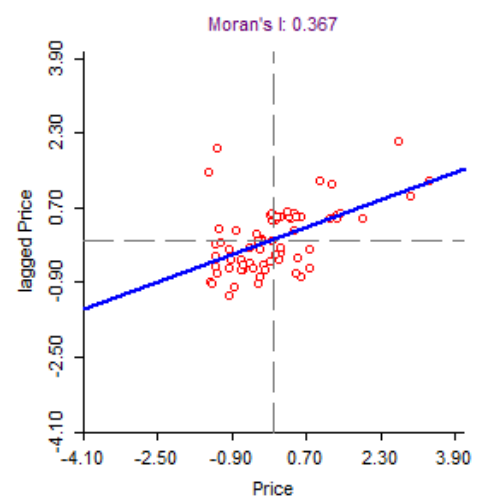

Figure 3. Moran's I univariant dispersion diagram for water price $(P)$

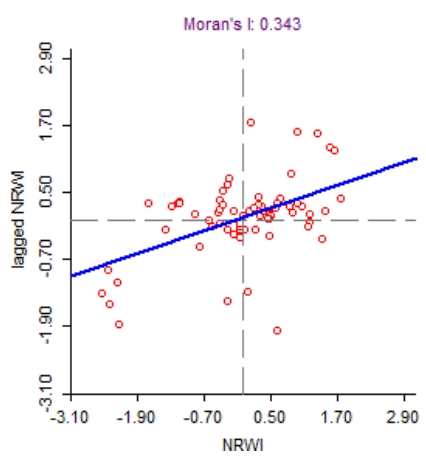

Figure 4. Moran's I univariant dispersion diagram for NRWI 
It is worth mentioning that autocorrelation for $P$ and $N R W I$ results are statistically significant from randomization based on 9999 permutations (Figure 5). This is stated, as in both cases, the value of the statistic is higher than the expected reference value $(\mathrm{E}[\mathrm{I}])$ described in the methodology, being in this case $\mathrm{E}(\mathrm{I})=(-) 0.0145$. Therefore, the null hypothesis of spatial randomness is rejected. In general, exploratory findings suggest that water management variables depend on what happens in neighboring locations.

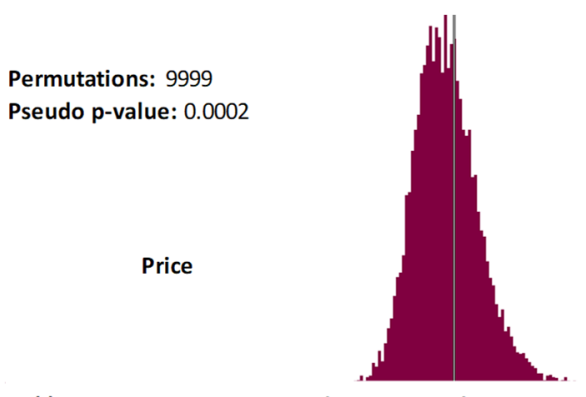

E(I):-0.0145 mean: -0.0147 Sd: 0.0709 Z-value: 5.3847

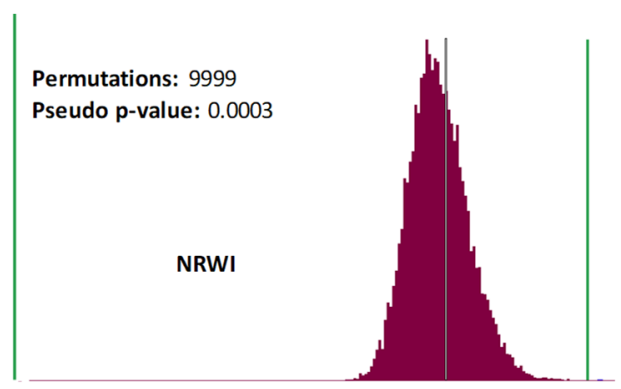

E(I):-0.0145 mean:-0.0144 Sd: 0.0721 Z-value: 4.9567

Figure 5. Empirical distribution of permutations for Moran's I

In order to determine the existence of spatial effects, it is first necessary to test for the spatial autocorrelation of the OLS model residuals, whose results are reported in Table 3. As can be seen, positive spatial autocorrelation is detected. The tests' results to identify the spatial specification of the model through ordinary and robust Lagrange multipliers indicate that the spatial autocorrelation is in the perturbance, so the best fit is expected through a spatial error model.

Table 3. Tests for Spatial Autocorrelation in the Residuals of the OLS Equation

\begin{tabular}{lccc}
\multicolumn{1}{c}{ Test } & Moran's I /Degrees of freedom & Z Value & P Value \\
\hline Moran's I (residuals) & 0.177 & 2.904 & 0.003 \\
Lagrange Multiplier (lag) & 1 & 2.606 & 0.106 \\
Robust Lagrange Multiplier (lag) & 1 & 1.444 & 0.229 \\
Lagrange Multiplier (error) & 1 & 4.260 & 3.097 \\
Robust Lagrange Multiplier (error) & 1 & 5.039 \\
Lagrange Multiplier (*SARMA) & 2 & 5.704 & 0.078 \\
\hline
\end{tabular}

Note. * Spatial Autoregressive Moving Average.

Thus, the spatial error model was estimated through the maximum likelihood method, whose results are presented in Table 4. Based on the Akaike criterion and the log-likelihood, it showed a better fit than the OLS model. Despite coefficients of the variables show consistency with the results found in OLS, the variable NRWI was not significant; meanwhile, the Lambda coefficient that measures the spatial autocorrelation in the error term is highly significant.

In sum, the evidence points out that the towns' contiguity explains the water billed volume. Perhaps because the closer the locations are to each other, the more they share sources of water extraction and use, whose management can lead to similar operating policies and the dissemination of management practices among UWU that face similar challenges. For example, the challenges faced by the localities of Nuevo León may be more similar than those faced by the localities of Sonora, or even, within the same state, there may be different conditions, as in the case of the Laguna Region with the Central region of the state of Coahuila. Consequently, results imply what happens in one locality is determined by what happens in the others, but the lesser the Euclidean distance from the centroids of their polygons, the greater the influence. The latter is due to the inverse distance contiguity criterion implemented in this work (See equation 9 in the methodology section). 
Table 4. Spatial error model by Maximum Likelihood; determinants of $\ln$ BV

\begin{tabular}{|c|c|c|c|c|c|c|c|c|c|}
\hline & Constant & $\begin{array}{c}L n \\
N R W I\end{array}$ & $\ln P$ & $\ln C O N N$ & Lambda & $\begin{array}{l}\text { Observa } \\
\text { tions }\end{array}$ & $\mathrm{R}$ square & $\ln L$ & $\begin{array}{l}\text { Akaike } \\
\text { criterion }\end{array}$ \\
\hline Coefficient & $5.725 * * *$ & -0.112 & $-0.237 * * *$ & $1.041 * * *$ & $0.386 * * *$ & & & & \\
\hline Z-Value & 13.464 & -1.270 & -5.793 & 63.944 & 2.727 & 70 & 0.988 & 13.264 & -18.529 \\
\hline P-Value & 0.0001 & 0.204 & 0.0001 & 0.0001 & 0.006 & & & & \\
\hline
\end{tabular}

Note. $* * *$ denote the statistical level of significance at $1 \%$.

In general, our findings indicate that water billed volume, which is used as a proxy for demand, is sensitive to price variations. This relationship, though, is inelastic, which means that price increases should be very high in percentage terms, but perhaps not so high in absolute terms due to the huge variation in prices charged by agencies. Interestingly, the results of ESDA at the univariate level revealed the existence of spatial association in two of the analyzed variables. Then spatial dependence was confirmed as the model presented evidence for spatial autocorrelation in the residual, estimated through a spatial error model by maximum likelihood. As a possible explanation, we assume the role of geological composition and interconnection of groundwater basins. We consider this information very important for the decision making of UWU since the results suggest that their actions impact neighbors, so — regional-joint decisions need to be made or at least among the closest operating agencies.

\section{Conclusions and Implications}

Our work represents a step forward in the study of performance in urban water management in the northern border region of Mexico. Price as an instrument for controlling water consumption does not offer an efficient alternative for reducing it, as water price increases would have to rise very high to reflect changes in consumption habits. Of course, under the assumption, the rest of the variables remain constant because other variables were not analyzed here, such as climate, income, and economic growth, which can certainly influence water demand.

Consequently, we argue that water price can be used as a revenue-raising tool to help UWU improve its efficiency levels. However, to take this path, the first step depends on legislation at the national level that sets clear, measurable, and achievable objectives. Otherwise, if its principles remain ambiguous, without performance parameters, no instrument or policy will be robust enough to meet the current and future challenges for ensuring water supply.

On the other hand, UWU in the region are not operating with acceptable efficiency standards, and on average, half of the water supplied is not billed. Evidence of inadequate resource management, thereby putting at risk its supply not only for the future but also for the present. As we stated, since the water supply is provided almost entirely by public entities, the rule of law and institutional quality are elements that influence operational and financial results. However, the latter was not directly included in our model, so the analytical scope could be extended in the future by proxying these variables.

A noteworthy aspect is that the region is highly dependent on water surface sources, so strategies should be implemented to keep them a sustainable option and mitigate the growing pressure on aquifers shared by several towns.

Finally, based on the results, we suppose that the connection between sources of supply in the region is why a significant spatial autocorrelation is found among UWU. Given the results and characteristics of water resources in the region, it is necessary to address the issue integrally and that public policy actions (e. g. urban and social development policies) be designed and implemented with this approach and with a long-term scope. To be effective, the management policies implemented by each operating agency must consider the participation of their regional counterparts.

\section{Acknowledgments}

This article has benefited from critique and feedback on early drafts of this manuscript. Also, we are grateful to anonymous reviewers for comments and suggestions. All remaining errors of fact or interpretation are the sole responsibility of the authors. We want to highlight that the authors contributed equally to the study. 


\section{References}

Acevedo, I., \& Velásquez, E. (2008). Algunos conceptos de la econometría espacial y el análisis exploratorio de datos espaciales. Ecos de Economía, 12(27), 2-9.

Anselin, L. (1980). Estimation methods for spatial autoregressive structures. Regional Science Dissertation \& Monograph Series. Program in Urban and Regional Studies, Cornell University (8).

Anselin, L. (1988). Spatial econometrics: Methods and models. Amsterdam: Kluwer Academic Publishers.

Anselin, L. (1994). Exploratory spatial data analysis and geographic information systems. In En M. Painho (Ed.), New tools for spatial analysis (pp. 45-54). Luxembourg: Eurostat.

Anselin, L. (1995). Local indicators of spatial association-LISA. Geographical Analysis, 27(2), 93-115.

Anselin, L. (1996). The Moran scatterplot as an ESDA tool to assess local instability in spatial association. In En M. Fischer et al. (Eds.), Spatial analytical perspectives on GIS: GISDATA 4 (pp. 111-125). London: Taylor \& Francis.

Anselin, L. (2004). Exploring spatial data with GeoDaTM: a workbook. Urbana, 51, 61801.

Arbia, G. (2014). A primer for spatial econometrics with applications in R. Palgrave MacMillan.

Arbués, F., Garcia-Valinas, M. A., \& Martínez-Espiñeira, R. (2003). Estimation of residential water demand: A State-of-the-art review. Journal of Socio-Economics, 32(1), 81-102.

Avilés-Polanco, G., Almendarez-Hernández, M. A., Hernández-Trejo, V., \& Beltrán-Morales, L. F. (2015). Elasticidad-precio de corto y largo plazos de la demanda de agua residencial de una zona árida. Caso de estudio: La Paz, B.C.S., México. Tecnología y Ciencias del Agua, 6(4), 85-99.

Barkin, D., \& Klooster, D. (2006). Estrategias de la gestión del agua urbana en México: un análisis de su evolución y las limitaciones del debate para su privatización. In D. B. (Ed.), La gestión del agua urbana en México retos, debates y bienestar- (pp. 1-46). México, D. F.: Universidad de Guadalajara.

Bunge, V. (2010). La disponibilidad natural de agua en las cuencas de México. In H. C. (Ed.), Las cuencas hidrográficas de México: diagnóstico y priorización (pp. 46-49). México, D. F.: Semarnat-Instituto Nacional de Ecología-Fundación Gonzalo Río Arronte.

Castro, G. (2014). Oferta y demanda de agua urbana en México: patrones y tendencias recientes. Universidad Autónoma de Coahuila.

Castro, G., \& Sisto, N. P. (2015). Precio y manejo del agua urbana en México. Nóesis. Revista de Ciencias Sociales y Humanidades, 24(47).

Chasco, C. (2003). Métodos gráficos del análisis exploratorio de datos espaciales. Anales de Economía Aplicada. Reunión anual de ASEPELT. España.

CONAGUA. (2014). Situación del Subsector Agua Potable, Alcantarillado y Saneamiento, Edición 2014. Coyoacán, México D. F.: Secretaría de Medio Ambiente y Recursos Naturales.

CONAPO. (2018). Proyecciones de la población de México, de las entidades federativas, de los municipios y de las localidades 2016-2050, México, CONAPO.

Contreras, H. (2006). Tienen los organismos de agua en México los incentivos para lograr una gestión eficiente de los servicios de agua potable, alcantarillado y saneamiento? In D. B. (Ed.), La gestión del agua urbana en México -retos, debates y bienestar- (pp. 75-102). México, D. F.: Universidad de Guadalajara.

Dall'erba, S. (2005). Distribution of regional income and regional funds in Europe 1989-1999: An exploratory spatial data analysis. Annals of Regional Science, 39(1), 121-148.

Dalhuisen, J. M., Florax, R. J. G. M., de Groot, H. L. F. M., \& Nijkamp, P. (2001). Price and income elasticities of residential water demand: Why empirical estimates differ. Tinbergen Institute Discussion Papers.

Dalhuisen, J. M., Florax, R. J. G. M., de Groot, H. L. F., \& Nijkamp, P. (2003). Price and income elasticities of residential water demand: a meta-analysis. Land Economics, 79(2), 292-308. https://doi.org/10.2307/3146872

Danilenko, A., Dickson, E., \& Jacobsen, M. (2010). Climate Change and Urban Water Utilities: Challenges and Opportunities. Water P-Notes; No. 50. World Bank, Washington, DC. Retrieved from https://openknowledge.worldbank.org/handle/10986/11696

Espey, M., Espey, J., \& Shaw, W. D. (1997). Price elasticity of residential demand for water: A meta-analysis. Water Resources Research, 33(6), 1369-1374. https://doi.org/10.1029/97WR00571 
Esqueda, R. (2018). Disparidades en el desarrollo regional en Tamaulipas, México. Revista de Economía Institucional, 20(38), 235-262. https://doi.org/10.18601/01245996.v20n38.10

Fullerton, T. M., \& Nava, A. C. (2003). Short-term water dynamics in Chihuahua City, Mexico. Water Resources Research, 39(9), 1258. https://doi.org/10.1029/2003WR002056

Fullerton, T. M., Tinajero, R., \& Mendoza, J. (2007). An Empirical Analysis of Tijuana Water Consumption. Atlantic Economic Journal, 35(3), 357-369. http://doi.org/10.1007/s11293-007-9074-X

García-Salazar, J. A., \& Mora-Flores, J. S. (2008). Tarifas y consumo de agua en el sector residencial de la Comarca Lagunera. Región y Sociedad, 20(42), 119-132. https://doi.org/10.22198/rys.2008.42.a511

Guzmán-Soria, E., Hernández-Martínez, J., García-Salazar, J. A., Rebollar-Rebollar, S., de la Garza-Carranza, M. T., \& Hernández-Soto, D. (2009). Consumo de agua subterránea en Guanajuato, México. Agrociencia, 43(7), 749-761.

House-Peters, L. A., \& Chang, H. (2011). Urban water demand modeling: Review of concepts, methods, and organizing principles. Water Resources Research, 47(5). https://doi.org/10.1029/2010WR009624

INEGI. (2011). Principales Resultados del Censo General de Población y Vivienda 2010.

INEGI (2017). Principales Resultados de la Encuesta Intercensal de Población y Vivienda 2015.

Jaramillo-Mosqueira, L. A. (2003). Modelando la demanda de agua de uso residencial en México. Documento de Trabajo, INE-DGIPEA/01/03.

Le Gallo, J. \& Ertur, C. (2003). Exploratory spatial data analysis of the distribution of regional per capita GDP in Europe 1980-1995. Papers in Regional Science, 82(2), 175-201.

Messner, S. F., Anselin, L., Baller, R. D., Hawkins, D. F., Deane, G., \& Tolnay, S. E. (1999). The Spatial Patterning of County Homicide Rates: An Application of Exploratory Spatial Data Analysis. Journal of Quantitative Criminology, 15(4), 423-450. https://doi.org/10.1023/A:1007544208712

Moran, P. (1948). The interpretation of statistical maps. Journal of the Royal Statistical Society. Series B (Methodological), 10(2), 243-251.

Moreno, R., \& Vayá, E. (2000). Técnicas econométricas para el tratamiento de datos espaciales: La econometría espacial. Barcelona, España: Edicions Universitat de Barcelona.

Nauges, C., \& Whittington, D. (2010). Estimation of water demand in developing countries: An overview. The World Bank Research Observer, 25(2), 263-294. https://doi.org/10.1093/wbro/lkp016

Reynaud, A., \& Romano, G. (2018). Advances in the Economic Analysis of Residential Water Use: An Introduction. Water, 10(9), 1162. https://doi.org/10.3390/w10091162

Ries, M., Lape, J., Broaddus, L., Sands, K., Ellis, J., \& Stephan, S. (2016). Sustainability Managers and the Transformation of the Water Utility. Proceedings of the Water Environment Federation. Water Environment Federation. United Sates. Retrieved from http://toc.proceedings.com/41061webtoc.pdf

Ruiz, K. (2010). Población por cuenca y zona funcional. In H. C. (Ed.), Las cuencas hidrográficas de México: diagnóstico y priorización, (pp. 60-63). México, D. F.: SEMARNAT-Instituto Nacional de EcologíaFundación Gonzalo Río Arronte.

Salazar, A., \& Pineda, N. (2010a). Escenarios de demanda y políticas para la administración del agua potable en México: el caso de Hermosillo, Sonora. Región y Sociedad, 22(47), 105-122.

Salazar, A., \& Pineda, N. (2010b). Factores que afectan la demanda de agua para uso doméstico en México. Región y Sociedad, 22(49), 3-16. https://doi.org/10.22198/rys.2010.49.a420

Satterthwaite, D. (2007). The Transition to a Predominantly Urban World and its Underpinnings. Human Settlements Discussion Paper Series, Urban Change 4, IIED, London.

Sisto, N. P. (2010). Manejo sustentable del uso de agua y crecimiento urbano. Ensayos Revista de Economía, 29(1), 23-38. http://doi.org/10.20983/noesis.2015.1.8

Water Advisory Council (2010). La gestión del agua en las ciudades de México. Indicadores de desempeño de organismos operadores. Consejo Consultivo del Agua, A. C. 


\section{Notes}

Note 1. Considering the criterion of localities of 2500 inhabitants or more, which is one of the most widely used standards.

Note 2. According to World Bank figures: https://data.worldbank.org/indicator/sp.urb.totl.in.zs

Note 3. Considering this criterion, in this region there are 152 urban localities, however, data availability regarding water management led us to use this sample (70) which is highly representative both in number (68.2 percent of the Northern Border State's total population) and geographical terms (see Appendix). It should be noted that some of the localities are metropolitan (e.g. Monterrey, Tampico, etc.).

Note 4. See Danilenko, Dickson \& Jacobsen (2010) for more details. They state that groundwater supplies are under stress due to decreasing precipitation rates and increasing extraction rates.

Note 5. In this paper, we refer to UWU as the urban water operating agencies that are responsible for water supply in Mexico.

Note 6. As explained above and in the methodology, we work with data from 70 urban water utilities, which in some cases supply water to metropolitan areas.

Note 7. We use this term as well as localities to refer to the units of study.

Note 8. So far, the most recent official data in Mexico.

Note 9. The figure is in current pesos. For international reference, the average monthly exchange rate in December 2019 was 0.052 US dollars per Mexican peso. According to official data from Banco de México: https://www.banxico.org.mx/SieInternet/consultarDirectorioInternetAction.do?\&sector=6\&accion=consultarDire ctorioCuadros\&locale $=$ es

\section{Appendix}

\section{Urban localities considered in the study}

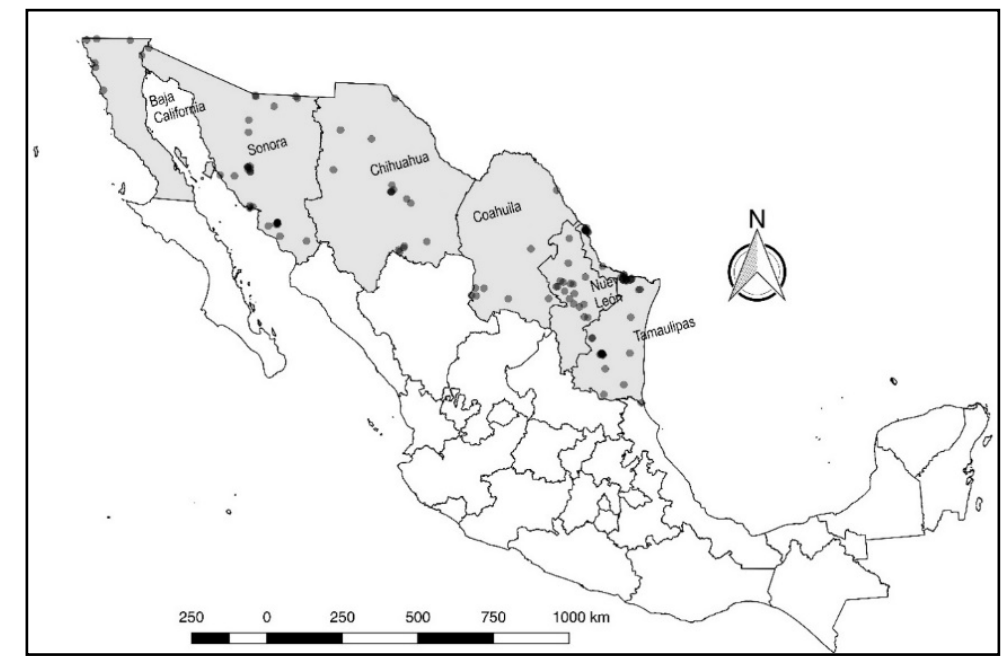

Source: Authors' elaboration.

\section{Copyrights}

Copyright for this article is retained by the author(s), with first publication rights granted to the journal.

This is an open-access article distributed under the terms and conditions of the Creative Commons Attribution license (http://creativecommons.org/licenses/by/4.0/). 